\title{
Metode Pembelajaran dengan Media Lagu untuk Meningkatkan Minat Belajar Firman Tuhan
}

\section{The Methods of Learning with Song Media for Enhancing Interest in God's Word Learning}

Cristie Febriyona $^{1)^{*}}$, Tri Supartini' ${ }^{2)}$, Like Pangemanan ${ }^{3)}$

\author{
1) Prodi Pendidikan Agama Kristen Sekolah Tinggi Filsafat Jaffray Makassar, Indonesia \\ 1) Prodi Pendidikan Agama Kristen Sekolah Tinggi Filsafat Jaffray Makassar, Indonesia \\ 1) Prodi Pendidikan Agama Kristen Sekolah Tinggi Filsafat Jaffray Makassar, Indonesia \\ *)Penulis korespondensi: cfyonnal6@gmail.com
}

Received: 19 January 2019/Revised: 15 February 2019 /Accepted: 06 April 2019

\begin{abstract}
Abstrak
Tujuan penulisan ini adalah menerapkan metode pembelajaran melalui lagu untuk meningkatkan minat belajar firman Tuhan. Metode yang digunakan adalah kualitatif yaitu observasi, wawancara terhadap subjek penelitian. Kesimpulan penelitian ini adalah 1) metode lagu dalam pembelajaran bagi anak usia 6-8 tahun sebaiknya dibuat sederhana dengan pilihan interval note 1-5 dan menggunakan irama yang lincah sehingga anak-anak lebih mudah dan tertarik untuk mempelajarinya; 2) minat belajar anak untuk mempelajari firman Tuhan, anak-anak perlu ditimbulkan minat belajarnya supaya anak-anak dapat memiliki dorongan dalam dirinya untuk mempelajari fiman Tuhan; 3) kajian metode pembelajaran dengan lagu terhadap minat belajar firman Tuhan dapat meningkatkan perhatian anak terhadap pelajaran, membuat anak merasa senang saat belajar, dan keterlibatan anak-anak juga cukup aktif dalam pembelajaran.
\end{abstract}

Kata-kata kunci: metode, lagu, pembelajaran, minat, belajar, firman Tuhan

\begin{abstract}
The purpose of this paper is to apply learning methods with song media to increase interest in learning God's word. The method used is qualitative, namely observation, interviews with research subjects. The conclusion of this study is 1 ) the method of song in learning for children aged 6-8 years should be made simple with a choice of interval notes 1-5 and using an agile rhythm so that children are more accessible and interested in learning it; 2) children's learning interest to learn the Word of God, children need to have an interest in learning so that children can have an urge in themselves to learn God's Word; 3) study of learning methods with songs on the learning interest the Word of God can enhance children's attention to learning, make children feel happy when learning, and the involvement of children is also quite active in education.
\end{abstract}

Keyword: methods, songs, learning, interests, learning, God's Word 


\section{Pendahuluan}

Dasar kepribadian seseorang terbentuk pada masa anak-anak. Gembala, guru-guru atau pendidik di sekolah minggu, dan juga pelayanpelayan anak dapat memahami kebutuhan anak-anak bertumbuh, dan berkembang dengan cara mendapatkan pengajaran yang terbaik dari sejak kecilnya, terutama pengajaran tentang firman Tuhan. Dalam kitab Ulangan 6:7, "Haruslah engkau mengajarkannya berulang-ulang kepada anak-anakmu dan membicarakannya apabila engkau duduk di rumahmu, apabila engkau sedang dalam perjalanan, apabila engkau berbaring dan apabila engkau berbaring, dan apabila engkau bangun." ${ }^{1}$

Dengan demikian, sudah seharusnya dalam mengajar, persiapan sangat perlu bagi seorang pendidik. Selain itu, pada umumnya para guru cenderung hanya menggunakan metode bercerita dalam mengajar. Hal ini tentu tidak efektif mengingat ada begitu banyak metode yang dapat digunakan untuk mengajar. Selain metode pembelajaran yang tidak pernah berubah, lagu-lagu di dalam kelas sekolah minggu juga sangat terbatas. Penyebab keterbatasan lagu-lagu yang dinyanyikan adalah karena tidak ada lagu-lagu baru yang diajarkan. Lagu merupakan sebuah teks yang dinyanyikan. Lagu berasal dari sebuah karya tertulis yang diperdengarkan dengan iringan musik. Mereka yang mendengarkan lagu bisa merasa sedih, senang, bersemangat, dan perasaan emosi lain karena efek dari lagu yang begitu menyentuh. Selain itu, lagu mampu menyediakan sarana ucapan yang secara tidak sadar disimpan dalam memori di otak. ${ }^{2}$

Di zaman modern ini, anak-anak lebih sering mendengar, dan menyanyikan lagu-lagu orang dewasa yang sebenarnya belum waktunya bagi mereka untuk memahami hal-hal yang terkandung dalam lirik lagulagu tersebut. Hal ini menjadi ancaman karena tidak semua lagu dapat mendidik anak dan sesuai dengan perkembangan anak. Namun dapat menjadi peluang untuk menggunakan sarana yang disukai anak-anak seperti media lagu untuk meningkatkan ranah kognitif, afektif, dan psikomotorik.

Melihat kurangnnya metode pembelajaran yang digunakan dan kurangnya lagu-lagu untuk anak-anak, maka perlunya menggunakan lagu sebagai metode pembelajaran. Sehingga anak-anak tidak hanya belajar lagu yang baru, tetapi mereka juga belajar firman Tuhan melalui lagu tersebut. Dengan demikian melalui metode pembelajaran ini, diharapkan 2014), 3-4.

${ }^{1}$ I Putu Ayub Darmawan, Menjadi Guru Yang Terampil (Bandung: Kalam Hidup,

${ }^{2}$ Muhimatul Ifadah, Siti Aimah, "Keefektifan Lagu Sebagai Media Belajar Dalam Pengajaran Pronounciation/Pengucapan," Seminar Hasil-hasil Penelitian (Semarang: Universitas Muhammadiyah Semarang, 2012), 364. 
anak-anak dapat menyanyikan dan mengingat firman Tuhan melalui lagu yang dinyanyikan.

\section{Kajian Teori}

\section{Metode Pembelajaran}

Pendidik berperan sebagai fasilitator yang berupaya membantu mengaitkan pengetahuan awal yang telah dimiliki peserta didik dengan informasi baru yang akan dipelajarinya. Pendapat Sudjana mengungkapkan bahwa metode pembelajaran adalah cara yang dipergunakan pendidik dalam mengadakan hubungan dengan peserta didik pada saat berlangsungnya pengajaran. Sementara Sutikno berpendapat metode pembelajaran adalah cara-cara menyajikan materi pelajaran yang dilakukan oleh pendidik agar terjadi proses pembelajaran pada diri peserta didik dalam upaya untuk mencapai tujuan. ${ }^{3}$ Salamun menambahkan bahwa metode pembelajaran ialah sebuah cara-cara yang berbeda untuk mencapai hasil pembelajaran yang berbeda di bawah kondisi yang berbeda. Hal itu berarti pemilihan metode pembelajaran harus disesuaikan dengan kondisi pembelajaran dan hasil pembelajaran yang ingin dicapai. ${ }^{4}$ Metode pembelajaran adalah cara kerja yang teratur dan bersistem untuk mencapai tujuan pembelajaran yang telah ditetapkan. Cara kerja dalam metode pembelajaran itu hendaknya menyajikan cara yang mudah dipahami, tidak rumit, mudah dan lama diingat, serta memberi suasana yang menggembirakan bagi peserta didik. ${ }^{5}$

Metode pembelajaran yaitu cara-cara yang dilakukan untuk mencapai hasil atau tujuan pembelajaran yang disesuaikan dengan kondisi pembelajaran.

\section{Pentingnya Penguasaan Metode Pembelajaran}

Ada begitu banyak alasan mengapa pendidik harus menguasai metode pembelajaran. Selain untuk menjadikan materi pelajaran menjadi menarik bagi peserta didik, berikut adalah beberapa alasan yang dapat diperhatikan dan dijadikan pembelajaran untuk para pendidik.

\section{Perbedaan Individual}

"Tuhan menjadikan setiap individu itu berbeda atau unik. Setiap individu memiliki kepribadian yang berbeda, bahkan anak kembar indentik sekalipun memiliki perbedaan. Setiap individu tidak memiliki

\footnotetext{
${ }^{3}$ Ihsana El Khuluqo, Belajar Dan Pembelajaran (Yogyakarta: Pustaka Pelajar, 2017), 129.

${ }^{4}$ Daryanto \& Syaiful Karim, Pembelajaran Abad 21 (Yogyakarta: Gava Media, 2017), 116.

${ }^{5}$ F. Thomas Edison, 52 Metode Mengajar (Bandung: Kalam Hidup, 2017), 18.
} 
kesamaan yang mutlak, yang ada hanya kemiripan." 6 Untuk cara belajar pun setiap individu memiliki perbedaan, ada yang senang belajar dalam keadaan tenang, tetapi ada juga yang lebih senang jika belajar dalam keadaan ribut atau sambil mendengarkan musik. Ada pula yang senang belajar berkelompok, tetapi tidak jarang ada individu yang saat sendiri mereka lebih maksimal dalam belajar.

Oleh sebab itu, dalam pembelajaran, "Pendidik perlu melakukan penelitian sederhana dengan cara menerapkan berbagai metode pembelajaran. Kemudian, pendidik dapat menganalisis metode mana saja yang sangat diminati oleh sebagian besar peserta didik dapat meningkatkan pemahaman peserta didik dengan lebih mudah." ${ }^{\text {" Dengan }}$ demikian peserta didik juga dapat sama-sama memperoleh hasil yang maksimal dalam belajar.

\section{Perbedaan Lingkungan}

Perbedaan lingkungan ini, meliputi alam, sosial dan kebudayaan. Setiap pendidik harus memperhatikan perbedaan lingkungan peserta didiknya, ia harus tahu dari mana mereka berasal, seperti apa tempat asal mereka, bahkan seperti apa orang-orang yang hidup di sekitarnya. ${ }^{8}$ Sebagai contoh, peserta didik yang berasal dari kota besar yang sudah tidak asing lagi dengan teknologi yang semakin berkembang pasti berbeda dengan murid yang berasal dari desa terpencil yang bahkan listrik saja tidak ada di desa tersebut. Jika pendidik mampu menguasai metode pembelajaran yang ada, pasti akan sangat membantu dalam mengajar meskipun terjadi perbedaan seperti ini.

\section{Adanya Faktor Kebosanan}

"Manusia mempunyai sifat mudah bosan." Kebosanan ini muncul karena pendidik hanya menggunakan metode yang sama dalam mengajar. Untuk mengantisipasi faktor kebosanan itu, hendaknya pendidik menguasai semua metode pembelajaran yang ada, agar materi pelajaran lebih bervariasi dan tidak membuat peserta didik jenuh dan bosan." 10 Metode dalam mengajar harus bervariasi untuk menghindari kebosanan.

\section{Keperluan Pembelajaran}

Dalam kegiatan pembelajaran ada beberapa strategi yang dapat digunakan dalam kegiatan pembelajaran, yaitu strategi pembelajaran

\footnotetext{
${ }^{6}$ F. Thomas Edison, 52 Metode Mengajar (Bandung: Kalam Hidup, 2017), 24.

${ }^{7}$ F. Thomas Edison, 52 Metode Mengajar, 24.

${ }^{8}$ F. Thomas Edison, 52 Metode Mengajar, 25-26.

${ }^{9}$ F. Thomas Edison, 52 Metode Mengajar, 26.

${ }^{10} \mathrm{~F}$. Thomas Edison, 52 Metode Mengajar, 26.
} 
aktif, inovatif, kreatif, efektif dan menyenangkan. "Dengan strategi aktif ini diharapkan akan tumbuh, dan berkembang segala potensi yang mereka miliki sehingga pada akhirnya dapat mengoptimalkan hasil belajar mereka."ll Jika suasana yang menyenangkan tersebut dapat terjadi di ruang kelas, maka pelajaran yang sukar pun akan terasa mudah untuk dipelajari dan hal-hal yang berat pun akan terasa lebih ringan. Oleh karena itu, perlu diusahakan supaya suasananya menyenangkan, tidak tegang. Walaupun demikian, pendidik tetap bersikap sopan, dan berintegritas. ${ }^{12}$

\section{Metode Joyful Noises}

"Metode Joyful Noises atau yang bisa disebut juga metode paduan suara dan musik adalah salah satu metode yang diajukan oleh Marlene LeFever dalam karyanya Creative Teaching Methods. Dengan metode ini peserta didik dibimbing bertumbuh dalam kemampuan kognitif, afektif dan psikomotor secara bersamaan. Mereka harus mengerti makna lirik lagu yang dinyanyikan, menyesuaikannya dengan musik, serta membangun keserasian dengan suara peserta didik yang lain."13 Metode lagu sangat menarik untuk digunakan karena lagu akan dinyanyikan secara berulang dan memiliki ritme yang kuat sehingga mudah dipelajari oleh anak-anak dan menjadikan lagu sebagai sesuatu yang akrab bagi anakanak. Lagu itu menyenangkan dan dapat memotivasi anak-anak. Banyak lagu yang dapat membantu mengembangkan memori dan konsentrasi, serta koordinasi fisik, misalnya ketika mendengar irama dari sebuah lagu anak-anak mulai bergerak mengikuti irama lagu. ${ }^{14}$ Metode ini mungkin jarang digunakan karena keterbatasan kemampuan bermusik atau bernyanyi seorang guru.

\section{Lagu Sebagai Metode Pembelajaran}

Metode pembelajaran melalui lagu ini sudah menjadi bahan penelitian bagi beberapa orang yang telah mencobanya dalam kegiatan belajar terutama untuk mempelajari bahasa. Melalui hasil penelitianpenelitian tersebut terlihat hasil yang memuaskan dari metode ini. "Seperti sebuah penelitian yang meneliti bahwa anak-anak yang mencitai musik dan yang dapat bernyanyi dengan rima yang teratur cenderung memiliki waktu lebih mudah untuk belajar berbicara dan mereka juga

${ }^{11}$ Hamzah B. Uno, \& Nurdin Mohamad, Belajar Dengan Pendekatan PAILKEM

(Jakarta: Bumi Aksara, 2017), 10.

${ }^{12}$ F. Thomas Edison, 52 Metode Mengajar (Bandung: Kalam Hidup, 2017), 28-29.

${ }^{13}$ B. S. Sidjabat, Menjadi Guru Profesional (Bandung: Kalam Hidup, 2009), 234.

14 "Kids and Songs," diakses 11 Juli 2018

https://www.teachingenglish.org.uk/article/kids-songs. 
menjadi lebih kreatif dan percaya diri." 15 Menyanyi dapat memberikan kepuasan, kegembiraan, dan kebahagiaan bagi anak sehingga dapat mendorong anak untuk belajar lebih giat (Joyful Learning). Dengan nyanyian seorang anak akan lebih cepat mempelajari, menguasai, dan mempraktikkan suatu materi ajar yang disampaikan oleh pendidik. Selain itu kemampuan anak dalam menyimak (listening), bernyanyi (singing), berkreativitas (creative) dapat dilatih melalui kegiatan ini. ${ }^{16} \mathrm{Hal}$ ini seharusnya menjadi perhatian pendidik bahwa, musik atau lagu secara khususnya memilik dampak yang begitu baik untuk pendidik gunakan dalam mengajar peserta didiknya.

\section{Lagu Untuk Anak}

Kebanyakan bentuk lagu/musik untuk anak TK adalah bentuk tunggal dan bentuk biner. Lagu bentuk tunggal atau bentuk kalimat satu, yang disebut A-A' apabila dalam ulangan ada sedikit perubahan. Lagu bentuk biner atau bentuk dua sederhana terdiri dari dua bentuk yang disebut A-B. Lagu/musik untuk TK biasanya pendek tetapi dengan ritme dan melodi yang menarik, lincah dan manis. ${ }^{17}$

\section{Manfaat Metode Lagu}

Berdasarkan penelitian yang banyak dilakukan, diketahui bahwa lagu dapat menyentuh 3 ranah pendidikan peserta didik, yaitu kognitif, afektif dan psikomotor anak. Jika dampak yang dihasilkan dari metode ini sangat baik seharusnya pendidik tidak perlu ragu lagi untuk menggunakan metode ini sebagai salah satu metode dalam kegiatan pembelajaran. Gordon berpendapat bahwa "pembelajaran musik pada usia dini akan lebih membantu membentuk fondasi yang kuat pada anak." 18

Selain itu ada beberapa manfaat metode pembelajaran melalui lagu yang bisa menjadi alasan penting mengapa pendidik harus menggunakan lagu sebagai metode pembelajaran: ${ }^{19}$

15 "The Importance of Learning Through Song," diakses 11 Juli 2018, https://www.earlychildhoodeducationzone.com/importance-learning-song/.

${ }^{16}$ Ira Miranti, Engliana, Fitri Senny Hapsari, "Penggunaan Media Lagu Anakanak Dalam Mengembangkan Kemampuan Kosakata Bahasa Inggris Siswa Di PAUD," Jurnal Ilmiah Kependidikan 2, no. 2 (Juli 2015): 170.

${ }^{17}$ Ibid., 170.

${ }^{18}$ Imam Ghozali, "Pembelajaran Musik Berbasis Siswa Dengan Pendekatan Local Genius," Jurnal Visi Ilmu Pendidikan 7, no. 1 (May 4, 2012): 651-63,

https://oi.org/10.26418/jvip.v7il.334.

${ }^{19}$ Thjin Chui Kiun, Marwani \& Halida, "Peningkatan Minat Belajar Bahasa Inggris Melalui Gerak Dan Lagu Di TK Kristen Immanuel Pontianak," Jurnal Pendidikan Dan Pembelajaran 4, no. 2 (November 2015): 3. 
1. Melalui musik atau lagu anak akan menemukan cara belajar yang menyenangkan.

2. Musik merangsang ketertarikan anak pada materi bidang ilmu yang lain.

3. Lagu memperkaya pengalaman belajar anak.

4. Lagu sebagai alat membantu mengingatkan informasi-informasi yang terpendam dalam ingatan anak.

5. Nyanyian dapat membantu memperkuat daya ingat anak.

6. Nyanyian merangsang kreatifitas dan membantu membentuk sikap yang positif anak untuk siap belajar di sekolah.

\section{Peranan Lagu Terhadap Kognitif, Afektif, dan Psikomotor}

Melihat bahwa lagu dapat mencakup kognitif, afektif dan psikomotor individu, maka akan dijelaskan peranan lagu terhadap masing-masing dari ranah pendidikan ini, yaitu kognitif, afektif, dan psikomotor.

\section{Perkembangan Kognitif}

Perkembangan kognitif berkaitan dengan proses berpikir, dengan pertumbuhan intelektual. Kognitif bersifat objektif, dan sering diukur oleh pendidik melalui ujian. ${ }^{20}$ Alkitab memerhatikan perkembangan kognitif. Dalam Matius 22:37, Yesus memerintahkan orang percaya untuk mengasihi Allah "dengan segenap hatimu, dan dengan segenap jiwamu, dan dengan segenap akal budimu." Roma 12:2 memerintahkan "Janganlah kamu menjadi serupa dengan dunia ini, tetapi berubahlah oleh pembaharuan budimu." Kematangan secara rohani memerlukan perkembangan intelektual. Sebagai pendidik anak ini adalah bertugas untuk peduli dengan pengembangan keterampilan kognitif.

Penelitian pembelajaran lagu anak untuk meningkatan pemahaman siswa pada mata pelajaran yang diajarkan. Pembelajaran lagu anak yang dibuat dengan memadukan unsur hiburan dan pendidikan, sehingga dapat dipergunakan sebagai media mengajar di dalam kelas. ${ }^{21}$ Musik/lagu dapat berkontribusi untuk perkembangan kognitif jika memilih teks kita dengan hati-hati, maksudnya adalah makna dalam setiap bait lagu tersebut haruslah berdasarkan pada kebenaran. Doktrin-doktrin di dalam Alkitab dapat dipelajari dengan mudah oleh anak kecil melalui pemilihan musik atau lagu substansial. Musik dapat membantu anak bukan untuk berpindah dari pencitraan ke realitas untuk pemahaman, melainkan akan

\footnotetext{
${ }^{20}$ Connie Fortunato, Children's Music Ministry: A Guide to Philosophy and Pratice (USA: David C. Cook Publishing Co., 1986), 100-102, 104.

${ }^{21}$ B. Subali, Idayani, and L. Handayani, "Pengembangan CD Pembelajaran Lagu Anak Untuk Menumbuhkan Pemahaman Sains Siswa Sekolah Dasar," Jurnal Pendidikan Fisika Indonesia 8, no. 1 (2012): 26-32, https://doi.org/10.15294/jpfi.v8il.1991.
} 
membantu anak mengartikulasikan kebenaran Alkitab yang penting. Area lain dari perkembangan kognitif yang sangat meningkat melalui musik adalah menghafal Alkitab. Banyak anak menghafal dengan mudah, (rupanya kemampuan untuk menghafal mencapai puncaknya sekitar usia tujuh tahun).

\section{Perkembangan Afektif}

Pembelajaran afektif termasuk pembelajaran emosional, pembelajaran nilai dan pengembangan karakter, bersama dengan apresiasi estetika. Melalui pendidikan afektif, bahan baku emosi diterjemahkan ke dalam perasaan, sikap dan nilai-nilai. Ada filsuf dan psikolog yang dari sejarah kuno berpendapat bahwa belajar kognitif tanpa pembelajaran afektif tidak hanya sia-sia tetapi berbahaya. Yang lain menunjukkan bahwa belajar yang tidak memengaruhi pengembangan karakter seseorang tidak ada gunanya. ${ }^{22}$ Sudah waktunya bagi komunitas Kristen untuk menyadari bahwa perkembangan kognitif saja tidak cukup bagi pendidikan Kristen karena kedewasaan secara rohani membutuhkan perkembangan emosional.

Musik tidak hanya penting dalam pendidikan kognitif, musik juga sangat penting dalam pendidikan afektif. Melalui partisipasi dalam musik, tidak hanya sikap dari lagu yang dipantulkan, tetapi sikap, perasaan, dan emosi dari pesertanya juga berubah atau dengan kata lain lagu dapat memengaruhi sikap, perasaan dan emosi seseorang yang mendengarkan lagu. Salah satu tantangan terbesar dari program musik anak-anak yang baik adalah menyediakan pengembangan sikap dan nilai alkitabiah, yang akan membantu anak-anak mengembangkan perasaan, dan emosi yang akan menghasilkan kerohanian yang sehat. Hal ini dapat dicapai dengan memberikan musik yang mencerminkan sikap alkitabiah seperti kasih, sukacita, damai sejahtera, kesabaran, kemurahan, kebaikan, kesetiaan, kelemahlembutan dan penguasaan diri.

\section{Perkembangan Psikomotor}

Pembelajaran psikomotor didefinisikan sebagai akusisi, retensi dan transfer gerakan sukarela. Pembelajaran psikomotor menunjukkan kontrol sukarela atas tindakan dan gerakan. ${ }^{23}$ Model alkitabiah kita untuk mengamati bahwa bertumbuh dalam Kristus menuntut tindakan yang merupakan hasil dari gerakan sukarela atau suatu perubahan yang terjadi bukan karena paksaan. Musik sangat penting dalam perkembangan psikomotor karena memiliki banyak aspek yang memerlukan 106, 110-111.

${ }^{22}$ Connie Fortunato, Children's Music Ministry: A Guide to Philosophy and Pratice, 105-

${ }^{23}$ Connie Fortunato, Children's Music Ministry: A Guide to Philosophy and Pratice (USA: David C. Cook Publishing Co., 1986), 111-112. 
koordinasi motor-otot dan partisipasi fisik. Tetapi perkembangan psikomotor tidak hanya sebatas untuk fungsi lompatan neuromuskular. Karena musik melibatkan anak dalam partisipasi aktif, itu meningkatkan ambang batasnya untuk belajar dan meningkatkan retensinnya.

\section{Pengertian Minat Belajar}

Siswa yang berminat terhadap suatu subyek tertentu biasanya akan memberikan perhatian yang lebih besar terhadap subyek itu. ${ }^{24}$ Minat tidak dibawa sejak lahir, melainkan diperoleh kemudian. Untuk dapat memahami apa itu minat atau minat belajar secara mendalam akan dijabarkan beberapa pengertian minat atau minat belajar agar lebih dipahami. Hernowo yang mengatakan bahwa minat adalah kecenderungan hati yang tinggi terhadap sesuatu. 25 Usman juga mengatakan minatbelajar besar sekali pengaruhnya terhadap hasil belajar sebab dengan minat seseorang akan melakukan sesuatu yang diminatinya. Sebaliknya tanpa minat seseorang tidak mungkin melakukan sesuatu. Misalnya seorang anak menaruh minat terhadap bidang kesenian, maka ia akan berusaha untuk mengetahui lebih banyak tentang kesenian. ${ }^{26}$

Dengan demikian minat belajar adalah suatu dorongan atau rangsangan dari dalam hati seseorang untuk mempelajari sesuatu yang akan dilakukan dengan sungguh-sungguh sehingga pelajaran tersebut tidak hanya berlalu begitu saja tetapi peserta didik dapat mengetahui lebih banyak tentang pelajaran tersebut, sehingga dampak dari hal ini adalah peserta didik dapat mengerti dan memahami pelajaran tersebut dan nilai-nilai dari pelajaran tersebut dapat mempengaruhi kehidupan sehari-hari peserta didik.

\section{Minat Belajar Firman Tuhan}

Minat belajar firman Tuhan adalah di mana anak-anak memiliki ketertarikan untuk lebih sungguh-sungguh mempelajari firman Tuhan. Dengan semakin banyaknya pengetahuan yang anak-anak dapat dari belajar firman Tuhan maka mereka tidak hanya tahu tetapi juga memahami isi firman Tuhan itu. Saat mereka memahami makna dalam kebenaran firman Tuhan, maka dalam kehidupan mereka sehari-hari pun

\footnotetext{
${ }^{24}$ Ahmad Susanto, Teori Belajar e Pembelajaran Di Sekolah Dasar (Jakarta: Prenadamedia Group, 2016), 16.

${ }^{25}$ Thjin Chui Kiun, Marwani \& Halida, "Peningkatan Minat Belajar Bahasa Inggris Melalui Gerak Dan Lagu Di TK Kristen Immanuel Pontianak, Jurnal Pendidikan Dan Pembelajaran 4, no. 2 (November 2015): 3; Hernowo, Menjadi Guru Yang Mau dan Mampu Mengajar Secara Menyenangkan (Bandung: MLC, 2005), 19.

${ }^{26}$ Keke T. Aritonang, "Minat Dan Motivasi Dalam Meningkatkan Hasil Belajar Siswa," Jurnal Pendidikan Penabur 10 (Juni 2008): 1l; Uzer Usman, Menjadi Guru Profesional (Bandung: Remaja Rosdakarya, 2003), 27.
} 
akan berlandaskan pada kebenaran firman Tuhan. Selain itu minat juga menjadi sumber motivasi yang kuat untuk belajar firman Tuhan yang membuat anak-anak berpartisipasi aktif dalam belajar firman Tuhan. Tanpa adanya minat belajar hasil dalam proses pembelajaran.

\section{Minat Belajar Anak}

Untuk dapat mengetahui apakah anak berminat dalam sebuah pembelajaran, maka diperlukan beberapa indikator dari minat belajar itu sendiri. Menurut Djamarahindikator minat belajar, yaitu rasa suka atau senang, pernyataan lebih menyukai,adanya rasa ketertarikan,adanya kesadaran untuk belajar tanpa di suruh, berpartisipasi dalam aktivitas belajar, dan memberikan perhatian. ${ }^{27}$ Slameto mengungkapkan beberapa indikator minat belajar, yaitu perasaan senang, ketertarikan, penerimaan, perhatian dalam belajar, motivasi belajar, pengetahuan, dan keterlibatan siswa. ${ }^{28}$ Berdasarkan definisi yang telah dikemukakan mengenai indikator minat, maka akan dijelaskan beberapa indikator minat belajar anak usia 6-8 tahun.

\section{Memusatkan Perhatian}

Seorang siswa yang menaruh minat besar terhadap pelajaran akan memusatkan perhatiannya lebih banyak dari pada siswa lain. Sehingga dengan demikian anak menjadi lebih giat untuk belajar dan bisa mendapat prestasi dalam belajar. ${ }^{29}$ Perhatian merupakan prasyarat utama dalam proses pembelajaran. Tanpa adanya perhatian hasil belajar yang dicapai peserta didik tidak akan tercapai secara optimal. Stimulus yang diberikan pendidik tidak akan berpengaruh tanpa adanya perhatian dari peserta didik. ${ }^{30}$

Anak-anak sulit untuk memusatkan perhatian bukan karena mereka tidak mau memerhatikan. Tetapi hal ini dikarenakan pelajaran yang mereka pelajari tidak menarik dan mereka merasa tidak mampu. ${ }^{31}$

\footnotetext{
${ }^{27}$ Ricky Darmawan, "Pengaruh Minat Belajar dan Perhatian Orang Tua Terhadap Prestasi Belajar Siswa Kelas Tinggi SD Negeri 01 Wonolopo Tahun Ajaran 2014/2015," (Skripsi, S.Pd, Universitas Muhammadiyah Surakarta, Juli 2015), 11-12, diakses 17 Juli 2018 http://eprints.ums.ac.id/35501/9/BAB\%20II.pdf; Syaiful Bahri Djamarah, PsikologiBelajar (Jakarta : Rineka Cipta), 132.

${ }^{28}$ Siti Nurhasanah \& A. Sobandi, "Minat Belajar Sebagai Determinan Hasil Belajar Siswa," Jurnal Pendidikan Manajemen Perkantoran 1, no. 1 (Agustus 2016):138, http://ejournal.upi.edu/index.php/jpmanper; Slameto, Belajar dan Faktor-Faktor yang Mempengaruhinya (Jakarta: Rineka Cipta, 2010).

${ }^{29}$ Ahmad Susanto, Teori Belajar \& Pembelajaran Di Sekolah Dasar (Jakarta: Prenadamedia Group, 2016), 16.

${ }^{30}$ M. Dalyono, Psikologi Pendidikan (Jakarta: Rineka Cipta, 1997), 203.

${ }^{31}$ Adi W. Gunawan, “Mengapa Anak Sulit Konsentrasi?” diakses 12 Juli 2018, http://www.adiwgunawan.com/Articles/Mengapa-Anak-Sulit-Konsentrasi.
} 
Oleh sebab itu, sudah seharusnya pendidik mampu membuat pelajaran menjadi menarik, karena saat pelajaran itu menarik maka rasa ketidakmampuan dalam mempelajarinya tidak akan terasa lagi.

\section{Keterlibatan Peserta Didik}

Keterlibatan langsung siswa memberi banyak sekali manfaat, baik manfaat yang langsung dirasakan pada saat terjadinya proses pembelajaran tersebut, maupun manfaat jangka panjang setelah proses pembelajaran terjadi. 32 Potensi-potensi anak hanya mungkin dapat dikembangkan, bilamana proses pembelajaran mampu melibatkan peran aktivitas intelektual, mental dan fisik anak secara optimal. ${ }^{33}$ Dengan kata lain, pendidik harus mampu membuat sebuah pembelajaran yang di dalamnya anak-anak dapat terlibat secara aktif gunakan mengembangkan potensi dalam diri mereka.

\section{Perasaan Senang}

Seorang peserta didik yang memiliki perasaan senang atau suka terhadap suatu pelajaran, pasti akan senang mempelajarinya. Mereka akan menerima pelajaran tersebut tanpa tertekan, mereka mau terus menerus mempelajarinya, tidak merasa terpaksa dalam belajar dan tidak bosan akan perlajaran tersebut. ${ }^{34}$ Perasaan senang yang timbul dalam pembelajaran merupakan sikap menerima atau kesediaan emosional untuk belajar, sehingga inilah yang akan membuat seseorang berusaha terlibat dalam kegiatan belajar dengan baik. ${ }^{35}$ Apabila seorang siswa memiliki perasaan senang terhadap pelajaran tertentu maka tidak akan ada rasa terpaksa untuk belajar. Perasaan senang yang dirasakan peserta didik dalam pembelajaran akan sangat membantu dalam proses belajar mengajar, karena perasaan senang ini akan membuat peserta didik tidak cepat merasa bosan dan mau terlibat aktif dalam pembelajaran.

\section{Metode}

Dalam penelitian ini, penulis akan menggunakan beberapa teknik dalam mengumpulkan data, antara lain:

Pertama, penulis mengumpulkan data dengan observasi partisipatif. Observasi partisipatif adalah suatu pengamatan yang dilakukan dengan terlibat langsung dengan orang atau kelompok yang sedang diamati atau

\footnotetext{
${ }^{32}$ Aunurrahman, Belajar dan Pembelajaran (Bandung: Alfabeta, 2016), 121.

${ }^{33}$ Aunurrahman, 120.

34 Sriana Wasti, Rahmiati Rahmiati, and Izwerni Izwerni, "Hubungan Minat Belajar Dengan Hasil Belajar Mata Pelajaran Tata Busana Di Madrasah Aliyah Negeri 2 Padang.," E-Journal Home Economic and Tourism 2, no. 1 (March 1, 2013): 5.

35 Aunurrahman, 179.
} 
yang menjadi sumber data dari penelitian, sehingga hasil yang diperoleh akan lebih lengkap, tajam, dan sampai mengetahui pada tingkat makna dari setiap perilaku yang tampak. ${ }^{36}$ Dalam penelitian ini, penulis melakukan observasi kepada 6 orang anak sekolah minggu GKII Unlimited Church yang saat ini berusia 6-8 tahun.

Kedua, penulis mengumpulkan data dengan wawancara yang dilakukan dalam penelitian agar penulis dapat mengetahui hal-hal dari responden yang lebih mendalam. ${ }^{37}$

Teknik analisis data yang akan penulis gunakan adalah analisis data kualitatif yang bersifat induktif, yaitu: Suatu analisis berdasarkan data yang diperoleh, selanjutnya dikembangkan pola hubungan tertentu atau menjadi hipotesis. Berdasarkan hipotesis yang dirumuskan berdasarkan data tersebut, selanjutnya dicarikan data lagi secara berulang-ulang sehingga selanjutnya dapat disimpulkan apakah hipotesis tersebut diterima atau ditolak berdasarkan data yang terkumpul. ${ }^{38}$

\section{Pengumpulan Data}

Dalam mengumpulkan data, penulis melakukan observasi selama kurang lebih 4 bulan mulai dari bulan Maret hingga bulan Juni. Penulis melakukan observasi yang dilaksanakan dua kali dalam satu bulan sesuai dengan jadwal yang diberikan bagi penulis untuk mengajar dalam kelas sekolah minggu, tetapi untuk bulan pertama dan kedua, penulis hanya melakukan observasi setiap satu bulan sekali dikarenakan kegiatan lain dalam sekolah minggu. Berikut ini adalah pemaparan mengenai waktu dan metode lagu yang penulis gunakan selama melaksanakan observasi.

Tanggal 18 Maret 2018: Tema: Excellent in Holiness; Nas: Amsal 15 (fokus pada ayat 3). Penulis (sebagai pengajar) memulai observasi pada bulan Maret dengan menggunakan lagu yang berjudul Hati-hati Gunakan Tanganmu. Secara kognitif melalui lagu ini anak-anak diajarkan untuk berhati-hati dalam melakukan sesuatu karena ada Tuhan yang melihat setiap apa yang mereka perbuat. Secara afektif anak-anak akan selalu berhati-hati dalam menjalani kehidupan mereka. Secara psikomotor anak-anak tidak akan memukul temannya saat bermain bersama-sama.

Tanggal 15 April 2018; Tema: Excellent in Self-image; Nas: Matius 19:1315. Pada bulan ini penulis menggunakan lagu Yesus Sayang Padaku untuk menjelaskan bahwa meskipun anak-anak sering dianggap belum bisa apaapa karena mereka masih kecil, mereka tetap tahu bahwa Tuhan Yesus menyayangi mereka. Berikut lirik dari bait kedua dari lagu Yesus Sayang

${ }^{36}$ Hengki Wijaya, Analisis Data Kualitatif Ilmu Pendidikan Teologi (Makassar:

Sekolah Tinggi Theologia Jaffray, 2018), 27-28.

${ }^{37}$ Wijaya, Analisis Data Kualitatif Ilmu Pendidikan Teologi, 36.

${ }^{38}$ Wijaya, Analisis Data Kualitatif Ilmu Pendidikan Teologi, 53. 
Padaku yang penulis tambahkan. Secara kognitif anak-anak dapat mengetahui bahwa Tuhan Yesus mengasihi mereka, sehingga Ia menyelamatkan mereka dari kematian kekal. Secara afektif anak-anak akan bersyukur atas kasih dan keselamatan yang Tuhan Yesus berikan bagi mereka. Secara psikomotor anak-anak akan mengasihi Tuhan.

Tanggal 6 Mei 2018; Tema: Excellent in Relationship; Nas: Kejadian 6:97:23. Pada awal bulan Mei penulis mengajarkan tentang seorang nabi, dan keluarganya yang diselamatkan Tuhan dari bencana besar yang menimpa seluruh bumi karena dia memiliki hubungan yang dekat dengan Tuhan, ia adalah nabi Nuh. Dalam cerita ini penulis menggunakan lagu Nabi Nuh yang sudah sering didengar anak-anak sekolah minggu. Secara kognitif anak-anak mengetahui bahwa Nuh diselamatkan beserta keluarganya. Secara afektif anak-anak sadar bahwa Nuh diselamatkan karena Nuh hidup bergaul dengan Tuhan. Secara psikomotor anak-anak hidup bergaul dengan Tuhan.

Tanggal 13 Mei 2018; Tema: Excellent in Relationship; Nas: Yohanes 15:13. Melalui cerita ini anak-anak diajak untuk mengenal bahwa mereka juga memiliki sahabat yang rela memberikan nyawa-Nya bagi mereka, yaitu Yesus Kristus. Yesus Kristus bukan hanya Tuhan tetapi Yesus adalah sahabat mereka yang sangat mengasihi mereka. Oleh sebab itu penulis membawakan lagu Yesus Sahabatku. Secara kognitif anak-anak tahu bahwa Yesus adalah sahabat mereka yang sangat mengasihi mereka. Secara afektif anak-anak semakin mengasihi Yesus sebagai sahabat mereka. Secara psikomotor anak-anak akan mengasihi sahabat-sahabat mereka.

Tanggal 3 Juni 2018; Tema: Excellent in Time; Nas: Mazmur 1:1-3. Dalam minggu pertama bulan Juni penulis mengajarkan tentang orang Kristen yang menggunakan waktunya siang dan malam untuk merenungkan firman Tuhan agar anak-anak dapat berakar, bertumbuh, berbuah "dan semua yang diperbuatnya berhasil". Oleh sebab itu penulis menggunakan lagu Firman Tuhan Ada Di Hatiku. Secara kognitif anak-anak tahu bahwa sebagai orang Kristen harus menggunakan waktu yang terbaik untuk merenungkan firman Tuhan. Secara afektif anak-anak mengerti kenapa harus merenungkan firman Tuhan. Secara psikomotor anak-anak mulai belajar untuk selalu merenungkan firman Tuhan.

\section{Pembahasan}

\section{Analisis Data Observasi dan Wawancara}

Minggu Pertama

Pada minggu pertama penulis melakukan observasi dengan cara menyanyikan lagu di awal cerita. Cara ini membuat semua anak 
memerhatikan penulis, karena semua ikut bernyanyi dan bergerak sesuai dengan yang penulis peragakan. Setelah diulang sebanyak 3 kali, penulis meminta anak-anak untuk duduk kembali lalu penulis memulai cerita dengan bertanya, "Tadi lagu kita mengatakan kita harus berhati-hati dalam menggunakan apa?" anak-anak menjawab silih berganti sesuai dengan lagu yang telah dinyanyikan. Kembali penulis menanyakan, "Kenapa kita harus hati-hati?" Gaby pun menjawab, "Karena Tuhan lihat miss." Setelah menanyakan pertanyaan tersebut, penulis menjelaskan ayat firman Tuhan yang dipelajari pada hari itu, dari 5 anak yang penulis teliti, hanya dua yang memerhatikan dengan duduk diam sambil melihat penulis yang sedang menjelaskan. Anak yang lain sibuk memotong pembicaraan dan mengganggu teman yang lain. Tetapi saat kembali diajak untuk menyanyikan lagu tersebut kembali, mereka merespons dengan semangat sambil tersenyum, dan ada yang melompat-lompat. Dalam minggu pertama, dapat dilihat bahwa ukuran untuk setiap indikator berada dalam posisi cukup dengan menggunakan metode lagu dalam mengajar firman Tuhan dengan cara menyanyikannya diawal cerita.

\section{Minggu Kedua}

Pada minggu ini penulis melakukan cara yang sama dalam menyampaikan cerita dengan metode lagu. Di awali dengan menyanyi sebelum memulai cerita, namun kali ini penulis tidak menggunakan gerak karena ada bait tambahan yang penulis ajarkan terlebih dahulu kepada anak-anak. Saat menyanyikan lagu, anak-anak mengikuti dengan saksama, sambil melihat penulis dan sesekali melihat lirik lagu yang penulis tuliskan di papan tulis. Setelah selesai menyanyikan lagu tersebut penulis tidak bertanya seperti yang penulis lakukan saat minggu pertama observasi, penulis langsung masuk ke dalam cerita, di mana saat bercerita penulis menghubungkan cerita tersebut dengan lagu yang dinyanyikan sebelumnya. Anak-anak masih seperti awal observasi, ada yang memerhatikan dengan melihat penulis selama menjelaskan, ada yang mengganggu penulis saat sedang menjelaskan dengan memotong perkataan penulis, dan ada juga yang mengganggu temannya yang sedang memerhatikan. Setelah cerita selesai, penulis kembali mengajak anakanak menyanyikan lagu tersebut, dan setelah selesai bernyanyi, penulis membuat sebuah game tanya-jawab di mana penulis menanyakan pertanyaan sehubungan dengan lagu dan cerita yang tadi sudah dipelajari bersama. Penulis memulai dengan pertanyaan berikut, "Siapa yang sayang pada kita?" Gaby menjawab "Tuhan Yesus miss", lalu penulis kembali bertanya "tadi dalam lagu kita dikatakan 'walau ku kecil lemah, aku ini milik-Nya,' pertanyaan miss, kita ini miliknya siapa?" Gaby kembali ingin menjawab, tetapi penulis memberikan kesempatan bagi yang lain untuk menjawab. Richard pun menjawab, "Saya miss, Tuhan Yesus." Setelah itu 
penulis kembali menanyakan pertanyaan yang lain, "Sekarang miss mau tanya ni, apa yang kita harus lakukan setelah kita sudah tahu bahwa Tuhan Yesus sangat mengasihi kita, ayo siapa yang bisa jawab?" tidak ada yang menjawab, lalu penulis menunjuk pada papan tulis di mana masih terdapat lirik dari lagu yang di dalamnya ada jawaban dari pertanyaan tadi. Penulis kembali menanyakan pertanyaan tersebut lalu Brillian akhirnya menjawab, "Bersyukur miss." Penulis melihat untuk indikator memerhatikan, dan keterlibatan secara aktif, anak-anak mengalami peningkatan. Tetapi untuk indikator senang, penulis belum dapat melihat peningkatan, dari minggu pertama sampai minggu kedua respons yang diberikan tetap sama.

\section{Minggu Ketiga}

Pada minggu ketiga di bulan yang baru penulis mencoba membawakan metode lagu dengan cara yang berbeda. Saat kelas di mulai, penulis memulai dengan penjelasan bahwa cerita hari ini akan menceritakan seseorang nabi tanpa menyebutkan namanya, lalu penulis juga menjelaskan sedikit cerita tentang Nuh sebagai pembuka tanpa menyebutkan namanya. Setelah itu penulis menyanyikan lagu tentang nabi Nuh dengan memotong-motong lagu tersebut dengan bertanya lalu dijawab dengan lagu tersebut. Cara ini membuat anak-anak bersemangat, selain karena mereka mengetahui lagu tersebut, mereka juga semangat untuk menjawab pertanyaan dengan menyanyikannya. Meskipun diawal mereka bingung dengan cara tersebut, tetapi akhirnya mereka pun mulai mengerti dan bersemangat untuk menjawab setelah diulangi kembali lagunya dengan pertanyaan yang berbeda tetapi yang jawabannya merupakan lirik lagunya. Dengan penjelasan yang sederhana cara ini mampu membuat anak-anak lebih memerhatikan penulis, karena dilihat dari antusia mereka saat menjawab pertanyaan dengan nyanyian dan juga salah satu dari mereka, yaitu Gaby mengatakan, "Ayo miss lagi miss" padahal saat itu pelajaran telah selesai dilakukan.

Dengan cara yang berbeda, terlihat berbeda pula hasilnya. Pada minggu ketiga, cara ini lebih membuat anak-anak dapat memerhatikan penulis saat menyampaikan cerita, sehingga terlihat antusia mereka dalam belajar, selain itu mereka juga dapat terlibat aktif dalam pelajaran minggu ini, karena jawaban mereka hanya terdapat dalam lirik lagu tersebut.

\section{Minggu Keempat}

Pada minggu ini, mengajarkan lagu baru sehingga penulis tidak menggunakan cara yang sama seperti waktu penulis menceritakan kisah nabi Nuh. Tetapi terlihat perubahan, saat akan memulai cerita, anak-anak sudah berkerumun untuk duduk dekat dengan penulis. Penulis memulai 
cerita minggu ini dengan bertanya apakah mereka memiliki sahabat, dan jawabannya berbeda-beda ada yang punya tetapi ada juga yang tidak, lalu penulis kembali bertanya, "Apa sahabat kalian selalu ada di mana kalian berada, misalnya seperti sekarang kalian ada di kelas ini, sahabat kalian ada juga atau tidak?" mereka menjawab tidak. Lalu penulis menjelaskan bahwa mereka memiliki sahabat yang akan selalu ada bersama mereka karena dia sangat menyayangi mereka. Setelah itu penulis mengajarkan lagu baru kepada mereka yang berjudul Yesus Sahabat ku, awalnya Richard menola untuk bernyanyi sehingga ia terus berbicara agar tidak jadi bernyanyi, namun saat penulis mulai bermain gitar, dan bernyanyi, mereka pun diam termasuk Richard dan memerhatikan penulis yang sedang bernyanyi, setelah itu penulis mengulang-ulang lagu tersebut, sampai mereka lumayan menguasainya. Pada minggu ini terlihat bahwa mereka lebih dapat memerhatikan pelajaran saat penulis mulai menyanyikan lagu. Keaktifan mereka pun mulai terlihat dengan selalu menjawab pertanyaan dari penulis, meskipun Joy masih malu-malu jika penulis mengajukan pertanyaan. Tetapi terlihat dia mengikuti selama penulis mengajar.

\section{Minggu Kelima}

Dalam minggu ini penulis menggunakan metode yang sama dengan minggu keempat. Hal ini bukan karena lagu yang penulis gunakan dalam minggu ini adalah lagu baru, tetapi pelajaran pada minggu ini agak sulit untuk mereka pahami. Mereka tahu lagunya, tetapi untuk memahami ayat yang mereka baca dalam Mazmur 1:3 mereka agak sedikit kesulitan karena saat diberikan pertanyaan, tidak ada seorang pun dari mereka yang menjawab. Sehingga penulis menyederhanakannya dengan bertanya, "Siapa yang rajin berdoa dan baca alkitab di sini?" semua anak-anak mengangkat tangannya. Penulis kemudian melanjutkannya dengan penjelasan yang menghubungkan dengan antara ayat yang ada di Alkitab dan juga lagu yang mereka ketahui.

Pada minggu ini, tidak ada begitu banyak perubahan pada anak, tetapi mereka tetap memberikan perhatian seperti Joel yang sudah jarang mengganggu temannya lagi saat mendengarkan cerita meskipun terkadang suka untuk berpindah-pindah tempat duduk. Keterlibatan mereka dalam minggu ini, agak sedikit berkurang dalam menjawab pertanyaan, namun untuk keterlibatan dalam bernyanyi mereka selalu bersemangat.

\section{Kesimpulan}

Pertama, metode lagu dalam pembelajaran bagi anak usia 6-8 tahun sebaiknya dibuat sederhana dengan pilihan interval note 1-5 dan 
menggunakan irama yang lincah sehingga anak-anak lebih mudah dan tertarik untuk mempelajarinya. Metode lagu juga sangat baik digunakan dalam pembelajaran karena memiliki peranan dalam perkembangan kognitif, afektif dan psikomotor anak. Di dalam Alkitab pun, metode ini telah digunakan untuk mengajar dan menegur seorang akan yang lain.

Kedua, minat belajar dalam diri seseorang menentukan orang itu akan serius dalam belajar atau tidak, karena dorongan atau rangsangan yang dapat membuat seseorang mau melakukan sebuah pembelajaran dengan sungguh-sungguh.

Ketiga, melalui kajian metode pembelajaran dengan lagu terhadap minat belajar firman Tuhan pada anak sekolah minggu usia 6-8 tahun, dapat meningkatkan perhatian anak terhadap pelajaran karena metode ini membuat anak merasa senang saat belajar, selain itu untuk keterlibatan anak-anak juga cukup aktif dalam pembelajaran.

\section{Kepustakaan}

Aritonang, Keke T. "Minat Dan Motivasi Dalam Meningkatkan Hasil

Belajar Siswa." Jurnal Pendidikan Penabur. 10 (Juni 2008): 11-21.

Atmodiwirjo, Ediasri T. Psikologi Anak dan Remaja. Jakarta: BPK, 1983.

Aunurrahman. Belajar dan Pembelajaran. Bandung: Alfabeta, 2016.

Dalyono, M. Psikologi Pendidikan. Jakarta: Rineka Cipta, 1997.

Djamarah, Syaiful Bahri. Psikologi Belajar. Jakarta: Rineka Cipta

Darmawan, I Putu Ayub. Menjadi Guru Yang Terampil. Bandung: Kalam Hidup, 2014.

Darmawan, Ricky. "Pengaruh Minat Belajar dan Perhatian Orang Tua Terhadap Prestasi Belajar Siswa Kelas Tinggi SD Negeri 01 Wonolopo Tahun Ajaran 2014/2015." Skripsi, S.Pd, Universitas Muhammadiyah Surakarta, Juli 2015. Diakses 17 Juli 2018. http://eprints.ums.ac.id/35501/9/BAB\%20II.pdf.

Daryanto \& Syaiful Karim. Pembelajaran Abad 21. Yogyakarta: Penerbit Gava Media, 2017.

Edison, F. Thomas. 52 Metode Mengajar. Bandung: Kalam Hidup, 2017.

Fortunato, Connie. Children's Music Ministry: A Guide to Philosophy And

Pratice. USA: David C. Cook Publishing Co., 1986.

Gunawan, Adi W. “Mengapa Anak Sulit Konsentrasi?” Diakses 12 Juli 2018. http://www.adiwgunawan.com/Articles/Mengapa-AnakSulit-Konsentrasi.

Ghozali, Imam. "Pembelajaran Musik Berbasis Siswa Dengan

Pendekatan Local Genius.” Jurnal Visi Ilmu Pendidikan 7, no. 1 (May 4, 2012): 651-63. https://doi.org/10.26418/jvip.v7il.334. 
Ifadah, M., Siti Aimah. "Keefektifan Lagu Sebagai Media Belajar Dalam Pengajaran Pronounciation/Pengucapan." Seminar Hasil-hasil Penelitian. Semarang: Universitas Muhammadiyah Semarang, 2012. Khuluqo, Ihsana El. Belajar Dan Pembelajaran. Yogyakarta: Pustaka Pelajar, 2017.

"Kids and Songs." Diakses 11 Juli 2018. https://www.teachingenglish.org.uk/article/kids-songs.

Kiun, Thjin C., Marwani \& Halida, "Peningkatan Minat Belajar Bahasa Inggris Melalui Gerak Dan Lagu Di TK Kristen Immanuel Pontianak." Jurnal Pendidikan Dan Pembelajaran 4, no. 2(November 2015):1-11.

Miranti, I., Engliana, Fitri Senny Hapsari. "Penggunaan Media Lagu Anak-anak Dalam Mengembangkan Kemampuan Kosakata Bahasa Inggris Siswa Di PAUD." Jurnal Ilmiah Kependidikan 2, no. 2 (Juli 2015): 167-173.

Nurhasanah, Siti \& A. Sobandi. "Minat Belajar Sebagai Determinan Hasil Belajar Siswa." Jurnal Pendidikan Manajemen Perkantoran 1, No. 1 (Agustus 2016):138. Diakses 17 Juli 2018 http://ejournal.upi.edu/index.php/jpmanper

Sidjabat, B. S. Menjadi Guru Profesional. Bandung: Kalam Hidup, 2009.

Slameto. Belajar dan Faktor-Faktor yang Mempengaruhinya. Jakarta: Rineka Cipta, 2010.

Subali, B., Idayani -, and L. Handayani. "Pengembangan CD Pembelajaran Lagu Anak Untuk Menumbuhkan Pemahaman Sains Siswa Sekolah Dasar." Jurnal Pendidikan Fisika Indonesia 8, no. 1 (2012): 2632. https://doi.org/10.15294/jpfi.v8il.1991.

Susanto, Ahmad. Teori Belajar \& Pembelajaran Di Sekolah Dasar. Jakarta: Prenadamedia Group, 2016.

"The Importance of Learning Through Song," diakses 1l Juli 2018 https:/www.earlychildhoodeducationzone.com/importancelearning-song/

Uno, Hamzah B. \& Nurdin Mohamad. Belajar Dengan Pendekatan PAILKEM Jakarta: Bumi Aksara, 2017.

Usman, U. Menjadi Guru Profesional. Bandung: Remaja Rosdakarya, 2003.

Wasti, Sriana, Rahmiati Rahmiati, and Izwerni Izwerni. "Hubungan

Minat Belajar Dengan Hasil Belajar Mata Pelajaran Tata Busana

Di Madrasah Aliyah Negeri 2 Padang." E-Journal Home Economic and Tourism 2, no. 1 (March 1, 2013): 1-14.

Wijaya, Hengki. Analisis Data Kualitatif Ilmu Pendidikan Teologi. Makassar: Sekolah Tinggi Theologia Jaffray, 2018. 